\title{
Using PaW-Modo to Enhance Paragraph Writing
}

\author{
Aderlin Chung Kim Yuk1, Florina Wang Wui-Xin1, Tan Pei Qin², Melor Md Yunus ${ }^{3}$ \\ ${ }^{1}$ SJKC Foon Yew 1, Johor Bahru, Malaysia \\ ${ }^{2} \mathrm{SJKC}$ Maran, Maran, Malaysia \\ ${ }^{3}$ Universiti Kebangsaan Malaysia, Bangi, Malaysia \\ Email: yuky92@gmail.com, florinawang18@gmail.com, tpeiqin087@gmail.com,melor@ukm.edu.my
}

How to cite this paper: Yuk, A. C. K. Wui-Xin, F. W., Qin, T. P., \& Yunus, M. M. (2019). Using PaW-Modo to Enhance Paragraph Writing. Creative Education, 10, 429-442.

https://doi.org/10.4236/ce.2019.102031

Received: December 21, 2018

Accepted: February 18, 2019

Published: February 21, 2019

Copyright (c) 2019 by author(s) and Scientific Research Publishing Inc. This work is licensed under the Creative Commons Attribution International License (CC BY 4.0).

http://creativecommons.org/licenses/by/4.0/

(c) (i) Open Access

\begin{abstract}
In Malaysian primary education, writing skills among the primary ESL learners have always been a focus since it is one of the major English language skills being accessed at the end of their primary education. Although much of the writing at the primary level is guided, it is found that the learners often shun the writing section and show a disinterested manner in learning. Therefore, a quasi-experimental research was conducted to explore the use of $\mathrm{PaW}$-Modo as a strategy in enhancing paragraph writing. The study involved a total of 42 Primary 4 pupils from an urban school, School A and a sub-urban school, School B. Data was collected via tests before and after the intervention, followed by a questionnaire comprising 4 closed-ended items and 2 open-ended items for $\mathrm{PaW}$-Burger and $\mathrm{PaW}$-Oreo activities in $\mathrm{PaW}$-Modo. The post-test result reflected the improvement in their writing skill and the findings from the questionnaire had also revealed that most of the pupils liked using PaW-Modo in writing activities. Therefore, this research would probably benefit both teachers and parents to guide their pupils to experience fun and meaningful learning in paragraph writing.
\end{abstract}

\section{Keywords}

PaW-Modo, Paragraph Writing, Primary ESL Learners, PaW-Burger, PaW-Oreo

\section{Introduction}

In recent years, the Industrial Revolution 4.0 (IR 4.0) has given a new impetus to educational transformation. Teaching, which has long been constrained by space and time (in which learning takes place in the class only) is soon coped with technology innovations such as mobile computing, cloud social network and big 
data. The fast and furious technological explosions allow personalised learning, which helps learners to explore and acquire knowledge and skills beyond the classroom boundaries (Zain, 2017). In order to prepare the learners for their future career development towards the IR 4.0, the instructions in the classroom are planned and implemented according to the 21st Century Learning Framework. Equipping with 21st century skills has become the main focus around the world as it highlights globalisation and internationalisation (Boholano, 2017). Among the 21 st century skills, the teachers and students have to possess self-direction, creativity, collaboration and innovation (Zakaria, Yunus, Nazri, \& Shah, 2016; Boholano, 2017).

Nowadays, individuals should adapt to changing and use technology innovations effectively and fruitfully in life (Ekici, 2017). In Malaysia, Ministry of Education (MOE) has realised the need for the education system to keep updated to the current trends, a proactive approach, which is the national education blueprint 2013-2025 has been launched. With the advancement of technology, the role of the teacher has to evolve upon meeting the demand by utilising technology in teaching. One way of achieving this is through the integration of online social networking into ESL (English as Second Language) writing classroom. It is proven that e-learning platform is effective in developing positive perception and attitudes towards writing, in terms of increasing pupils' learning motivation (Lan et al., 2011; Vanesa, 2013; Qalaja, 2015; Purnawarman et al., 2015), increasing enjoyment (Lan et al., 2011; Vanesa, 2013) and lowering anxiety (Kreutz \& Rhodin, 2016). Noticing how impactful the e-learning is, the researchers, thus, have chosen Edmodo as the platform of learning in this study. $\mathrm{PaW}$-Modo is then created specifically to enhance paragraph writing among the primary level pupils.

\section{Introduction on PaW-Modo}

PaW-Modo is an online writing platform that is transformed from the online social networking platform "Edmodo" (Modo) with the designation of PaW-Burger and PaW-Oreo activities in enhancing the learning of paragraph writing $(\mathrm{PaW})$. Paragraph writing begins from introduction, body/details and lastly the conclusion/ending. PaW-Burger activity uses a burger template which helps pupils focusing on the basic paragraph writing including an introduction, three supporting details and a concluding sentence in writing a paragraph. After the pupils learn and familiarize on the basic writing steps in PaW-Burger activities, it followed by another paragraph writing activity, PaW-Oreo which focuses on an introduction, three reasons with elaborations and conclude with a conclusion. PaW-Oreo differs from PaW-Burger at the body, in which each reason is followed by an elaboration in the Oreo template. The pupils could access and write on both PaW-Burger and PaW-Oreo templates in Edmodo.

Edmodo is in the form of a website and a mobile application designed for teachers, pupils and their parents which aids for collaboration, communication, 
the sharing of knowledge, homework and discussion between pupils, teachers and parents. Edmodo was created in 2008 by Nic Borg and Jeff O'Hara. The goal of Edmodo is to help educators harness the power of social media to allow easy customization of the classroom (Charoenwet \& Christensen, 2016). The reason Edmodo is chosen as the writing platform for this research because it contains minimal advertisements and it is free of games and other distractions that might interfere with pupils' learning. Besides that, Edmodo aids to complement face-to-face classroom interactions (Enriquez, 2014). It provides a virtual learning environment which allows teachers to communicate with their pupils, share materials and monitor pupils' progress. The disparity of Edmodo and other social networking is that Edmodo has built-in assessment tools such as quiz, poll, assignment, grade book and other tools that assist teachers in assessing pupils. Teachers can write messages about assignments, post related materials for assignments or held a discussion for the class. Pupils can also turn in their task while teachers can enter and manage grades.

\section{Issues in Writing}

There are many types of writing taught in the school but the most common type of writing is the guided paragraph writing. Out of all the language skills, writing is perceived to be the most difficult language skill to acquire (by the pupils) and to be taught (by the teachers) yet it is one of the most crucial English Second Language skills (Damian \& Yunus, 2016). Although much of the writing at the primary level is guided, it is found that the learners often shun the writing section and reflect disinterested manner when it comes to writing session in the classroom. It is always a challenge for teachers in order to make pupils fall in love with writing and stimulate them to personally engage themselves in the process of writing. The reason pupils write is only due to classroom-bound activities at schools. In order for the learners to be successful in writing, teachers need to choose suitable method, technique or media to assist pupils in writing. However, it was found that although teachers have an invaluable resource to draw from in this era of technological advancement, Information and Communications Technology (ICT) and the Internet, these sources of potential as a tool for learning in the classroom has not been fully exploited by the ESL educators (Yunus \& Salehi, 2012). There are numerous technology tools and methods for teaching writing that can make the learning process interesting and more fun for both teachers and pupils. The researchers had chosen Edmodo and turned it from a social network to a writing learning platform "PaW-Modo" in order to find out the effectiveness of PaW-Modo in helping pupils to improve their paragraph writing performance. The aims of the undertaking study are as below:

1) To investigate whether there is significant mean score difference between pre-test and post-test of the experimental group in School A and School B.

2) To investigate whether there is any mean score difference in pre-test and 
post-test between the experimental and controlled group in School A.

3) To investigate how pupils perceive toward the use of $\mathrm{PaW}$-Modo.

\section{Past Studies}

In this study, the researchers focused on paragraph writing as paragraph writing includes opinion writing and narrative writing that are being taught in Malaysian primary school syllabus. The main e-learning platform used in this study was limited to the use of Edmodo only. Studies that deal with other e-learning platform such as Moodle, Canvas, Facebook or Blackboard were excluded. From the past studies, it is found that web-based technologies are widely used in foreign countries. Vanesa Durán Lara (2013) and Lan et al. (2011) revealed that e-learning could help to improve the pupils writing skills as well as develop positive attitude. E-learning could be used in dealing with any type of writing. Lan et al. (2011) conducted the use of media richness theory in teaching and learning guided writing among sixth-grade students. Other researchers such as Is'haq et al. (2018) carried out the intervention of Edmodo in paragraph writing while Fauzi (2017) focus on using Edmodo in teaching and learning recount text students of a senior high school. Study by Qalaja (2015) concluded her results that the Edmodo group of students (experimental students) yielded better result in writing task performance compared to the non-experimental students. Melor Md Yunus \& Hadi Salehi (2012) also supported the idea of using social networking platforms as it is a learning tool that helps students to learn new vocabulary from peers' comments, reduce spelling error through spell-check feature, easily complete essays after group participation. The data collected from interview and the survey in the study (Lan et al., 2011; Vanesa, 2013; Qalaja, 2015; Purnawarman et al., 2015) had also proven that social networking platform is effective in increasing pupils' learning motivation, increasing enjoyment and lowering anxiety. Based on their research findings, the integration of ICT encourages learners to develop independent work habits and build both their skills and confidence in writing.

Besides, the study conducted by Purnawarman et al. (2015) to investigate how Edmodo as a learning platform in a blended learning setting in teaching writing, it is revealed that all the participants from the eleventh grade of a senior high school in Bandung, Indonesia experienced learner-content interaction, learner-instructor interaction and peer interaction through the Note Menu in Edmodo. This is in line with the findings from other researchers, Lan et al. (2011) and Qalaja (2015) that Edmodo could facilitate communication and interaction in many ways. Besides promoting virtual interactions, the study from Purnawarman et al. (2015) also found that Edmodo also facilitate students' cognitive engagement and cognitive processes in writing. Cognitive engagement was heightened to the extent that students were willing and able to take on the learning task at hand. With all the benefits of utilising ICT and using Edmodo, researchers have chosen this as the most suitable social learning platform for this study. 
From the past studies, it is found that many studies have been conducted to find out the effectiveness of Edmodo and perceptions of pupils towards Edmodo in secondary and higher learning institutions. However, none or fewer studies are conducted to investigate the effectiveness of Edmodo in teaching paragraph writing in Malaysian primary school setting and primary pupils' perception towards the use of Edmodo in learning paragraph writing. Therefore, this study seeks to bridge this gap. In addition, different from other past studies in which Edmodo was being the only tool in teaching and learning writing skills, Edmodo is further enhanced in this study with the innovation of PaW-Modo in which Paw-Burger and PaW-Oreo activities were devised and incorporated with Edmodo (an online writing platform) in helping pupils to write a paragraph effectively.

\section{Methodology}

In this study, a quasi-experimental approach was utilised to explore the effect of using PaW-Modo on developing paragraph writing skill of the primary 4 learners. There were 42 research participants involved in this study through random sampling from two different schools in Malaysia. The study was conducted for about 8 weeks.

\subsection{Research Participants}

The study was carried out in two schools in Malaysia, which were an urban school in the Southern end of Peninsular Malaysia, School A and a sub-urban school in East Coast Peninsular of Malaysia, School B. The targeted participants are Primary 4 pupils. With the limited amount of pupils in School B, all the 15 pupils of Primary 4 were selected to be the experimental group while in School A, an experimental group of 15 pupils and a controlled group of 12 pupils were included in this study. They were selected through purposive sampling based on their proficiency level and attendance rate.

\subsection{Research Instruments}

The research instruments consist of tests and questionnaires. For the tests, pre-test and post-test were designed to measure pupils' performance and progress in the organisation of ideas in paragraph writing. These tests were in a form of essay writing consisting of a question with a picture and some phrases given. The question in pre-test and post-test are similar in term of its content, structure and difficulty level. The data of pre-test and post-test were collected before and after the intervention. For the questionnaire, it comprised of 4 closed-ended items and 2 open-ended items. The questionnaire was carried out after the intervention of PaW-Burger and PaW-Oreo activities to identify how pupils perceived $\mathrm{PaW}$-Burger and $\mathrm{PaW}$-Oreo activities in learning paragraph writing. Dichotomous questions that asked for "Yes" or "No" response were used for the closed-ended items. 


\subsection{Research Procedures}

The researchers incorporated ADDIE (Analysis, Design, Development, Implementation and Evaluation) Model to develop this research from the planning stage until the evaluation stage. ADDIE Model is an instructional model used to develop the research procedure and lead the researchers to data collection and data analysis procedure (Gagne, Briggs, \& Wagner, 1992). The five stages of ADDIE Model are shown in Figure 1.

At analysis stage, the writing pre-test was carried out in School A and School $B$ to find out pupils' achievement and the problems they faced in writing a paragraph. A scoring rubric was used to measure their achievements in pre-test. Then, the current problems found in paragraph writing were analysed and some literatures and references related to the present issue were studied. At the design stage, PaW-Modo was innovated with the designation of PaW-Burger, PaW-Oreo activities and the help of Edmodo as a virtual learning platform in teaching and learning paragraph writing. Some useful sources in helping to design PaW-Modo project were collected such as its content, resources, activities, techniques and evaluation. This was also a planning stage in which the writing lessons were planned based on the syllabus in the textbook and the types of writing skills that the primary 4 pupils are required to master. The objectives of PaW-Modo project were also illustrated in which the experimental groups of pupils would be able to 1) Practise the technique of brain storming and drafting using the PaW-Burger and PaW-Oreo template; 2) Organise ideas in paragraphs; 3) Use punctuation marks correctly; 4) Spell the sight words and verbs correctly; 5) Write with correct sentence structure at the end of the intervention.

At the implementation stage, the experimental groups from School A and School B were given a training session on ways and rules to use PaW-Modo correctly in English writing class. Then, the pupils were introduced to the steps of writing a paragraph using $\mathrm{PaW}$-Burger and PaW-Oreo. Pupils were encouraged to actively participate in the genuine and virtual writing classroom. Assistance in the form of scaffolding and modelling were provided before they were asked to produce their own writing. Their works were graded by the teachers in Edmodo page while teachers' and peers' comments and feedback were being followed up outside the classroom. On the other hand, paragraph writing was taught to the controlled group by using conventional method, in which talk and chalk as well as paper and pen were involved. At the end of the implementation stage, the post-test of writing was conducted on both experimental and controlled group to investigate the pupils' writing performance with and without the intervention of PaW-Modo. The post-writing questionnaire was also administered to find out how the experimental groups of pupils perceived towards paragraph writing with the intervention of PaW-Burger and PaW-Oreo activities in PaW-Modo. At the evaluation stage, data from pre-test, post-test and questionnaires were collected and analysed to assess the effect of PaW-Modo towards pupils' writing performance and their perceptions towards paragraph writing. 


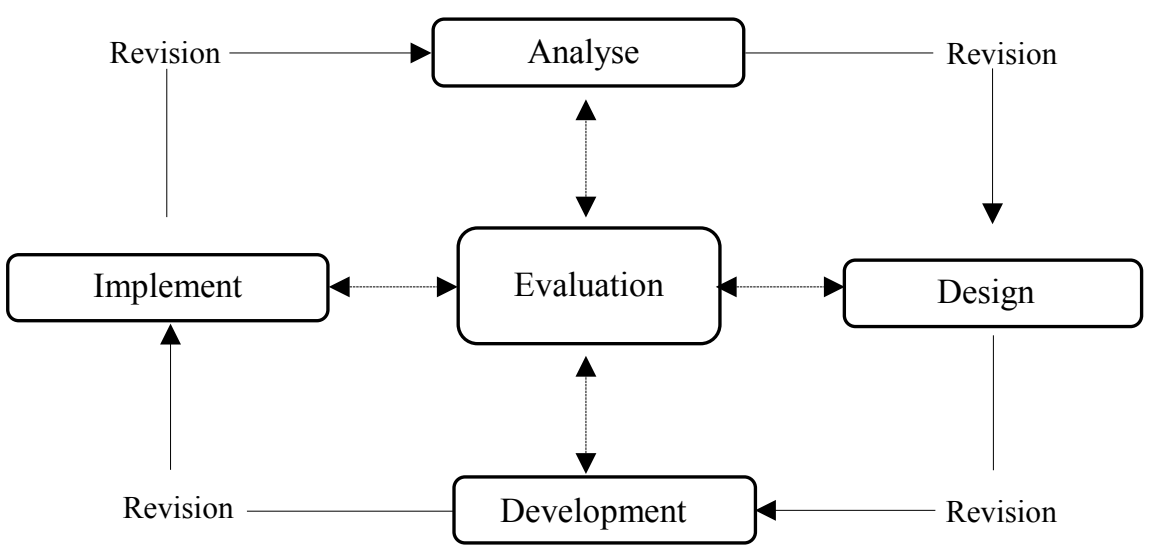

Figure 1. Using ADDIE model to develop instructional strategies for the research procedure.

\section{Findings and Discussions}

The findings would be discussed based on three main sections, which are the comparison of pre-test and post-test results of experimental groups between School A and School B, the comparison of pre-test and post-test between the experimental and controlled group in School A and participants' responses towards the use of PaW-Modo.

\subsection{Comparison of Pre-Test and Post-Test Results of Experimental Groups between School A and School B}

The pre-test result revealed that most of the participants in both schools failed to write English paragraph writing before the interventions were carried out. Based on Table 1, after the intervention, participant 13 and 15 in School B had zero improvements in writing. On the other hand, the participant 12 and 13 in School A had lower scores compared to previous writing test. The reason could be the less exposure in using technology in both schools. The unfamiliar in using ICT could be a reason why the participants could not learn writing well while using PaW-Modo. Much effort should be put by ESL educators by exploiting ICT in English lessons to increase the performance of pupils in writing (Yunus \& Salehi, 2012).

To analyse the difference between pre-test and post-test of two different schools, the results were calculated using mean and standard deviation score. As Table 2 shows, participants in School A obtained a mean score of 4.9 in post-test, which is larger than the mean score of 3.8 in the pre-test. Meanwhile, School B obtained a mean score of 3.1 in post-test, which is also higher than the mean score of 2.1 in the pre-test. The increment of mean score in both schools evidently indicates that, on average, the use of PaW-Modo has caused the improvement in pupils' scores. This is in line with the studies of the scholars (Qalaja, 2015; Purnawarman et al., 2015; Is'haq et al., 2018) who also proved positive writing performance among the ESL learners in using Edmodo towards their learning process. 
Table 1. Result of pre-test and post-test of the experimental groups in School A and School B.

\begin{tabular}{ccccccc}
\hline & \multicolumn{5}{c}{ School A } & \multicolumn{5}{c}{ School B } \\
\cline { 2 - 7 } Participants & Pre-Test & Post-Test & $\begin{array}{c}\text { Pre and Post Test } \\
\text { Scores Differences }\end{array}$ & Pre-Test & Post-Test $\begin{array}{c}\text { Pre and Post Test } \\
\text { Scores Differences }\end{array}$ \\
\hline 1 & 4 & 7 & +3 & 0 & 1 & +1 \\
2 & 3.5 & 4 & +1.5 & 4.5 & 6 & +1.5 \\
3 & 3.5 & 5.5 & +2 & 2 & 3 & +1 \\
4 & 6 & 8 & +2 & 3 & 3.5 & +.5 \\
5 & 1.5 & 2.5 & +1 & 2.5 & 4 & +1.5 \\
6 & 2.5 & 3.5 & +1 & 4 & 4.5 & +.5 \\
7 & 3.5 & 5.5 & +2 & .5 & 3 & +2.5 \\
8 & 3 & 4 & +1 & 0 & 1 & +1 \\
9 & 4.5 & 5 & +.5 & 2.5 & 3.5 & +1 \\
10 & 5.5 & 6 & +.5 & 3.5 & 4.5 & +1 \\
11 & 2.5 & 3.5 & +1 & 1 & 3.5 & +2.5 \\
12 & 3.5 & 2.5 & -1 & 3 & 3.5 & +.5 \\
13 & 6 & 4.5 & -1.5 & 1 & 1 & 0 \\
14 & 4 & 4.5 & +.5 & 4 & 4.5 & +.5 \\
15 & 3.5 & 7 & +3.5 & 0 & 0 & 0 \\
\hline
\end{tabular}

Table 2. Mean score and standard deviation of the experimental groups in School A and School B for pre-test and post-test.

\begin{tabular}{ccccc}
\hline \multirow{2}{*}{ School } & \multicolumn{3}{c}{ Pre-Test } & \multicolumn{2}{c}{ Post-Test } \\
\cline { 2 - 5 } & Mean & S.D. & Mean & S.D. \\
\hline A & 3.8 & 1.3 & 4.9 & 1.6 \\
B & 2.1 & 1.6 & 3.1 & 1.7 \\
\hline
\end{tabular}

\subsection{Comparison of Pre-Test and Post-Test between Experimental and Controlled Group in School A}

Based on Table 3, most of the participants from the experimental group showed improvement from a lower score in the pre-test to a higher score in the post-test. Meanwhile, only 9 participants in the controlled group show an increment of test score between pre-test and post-test. The small increment in the controlled group revealed that there is no much improvement in the post-test among the participants. From here, it showed that the experimental participants were able to build their confidence level in writing through the usage of ICT even though there were some with minimal ICT skills. As the results shown on comparison of experimental and controlled group, without the integration of technology in learning paragraph writing were seems to be a lacking factor in the teaching and learning. It was also proven by some researchers that when ICT was integrated to teach writing, the lesson appeared to be more interesting (Yunus et al., 2013a, 2013b). 
By further discussing on Table 4, it was clearly shown that the mean of the pre-test and post-test for the controlled group remained the same with the mean of 2.5 whereby the experimental group possessed an increment in the mean of the pre-test and post-test from 3.8 to 4.9. Based on the results, it revealed a substantial impact on the interventions which suggest that PaW-Modo is an effective tool to scaffold primary pupils in enhancing paragraph writing as compared to the conventional way of teaching writing. Balasubramanian, Jaykumar \& Fukey (2014) pointed out that Edmodo is a social learning platform designed for collaboration, communication, the sharing of knowledge, homework and discussion between pupils, teachers and parents.

The pre-test scores and the post-test scores between the experimental group and control group were further analysed by using paired sample t-test shown in Table 5. The result showed that there were significant mean score differences between the pre-test and post-test of experimental group in SJKC Johor Bahru, $[\mathrm{t}(14)=3.127, p<.05)]$ and in SJKC Maran, $[\mathrm{t}(14)=5.123, p<.05)]$. However, there were no significant mean score found between pre-test and post-test of the controlled group, [t(11) $=.0, p>.05]$. From the t-test analysis, we could conclude that $\mathrm{PaW}$-Modo group of students (experimental students) yielded a better result in writing task performance compared to the non-experimental students, which is also in line with the results in the study done by Qalaja (2015).

Table 3. Result of pre-test and post-test of the experimental group and control group in School A.

\begin{tabular}{|c|c|c|c|c|c|c|}
\hline \multirow[b]{3}{*}{ Participants } & \multicolumn{6}{|c|}{ School A } \\
\hline & \multicolumn{3}{|c|}{ Experimental Group } & \multicolumn{3}{|c|}{ Controlled Group } \\
\hline & Pre-Test & Post-Test & $\begin{array}{l}\text { Pre and Post Test } \\
\text { Scores Differences }\end{array}$ & Pre-Test & Post-Test & $\begin{array}{l}\text { Pre and Post Test } \\
\text { Scores Differences }\end{array}$ \\
\hline 1 & 4 & 7 & +3 & 6 & 6 & 0 \\
\hline 2 & 3.5 & 4 & +1.5 & 4 & 5 & +1 \\
\hline 3 & 3.5 & 5.5 & +2 & 1.5 & 2 & +.5 \\
\hline 4 & 6 & 8 & +2 & 3 & 3.5 & +.5 \\
\hline 5 & 1.5 & 2.5 & +1 & .5 & .5 & 0 \\
\hline 6 & 2.5 & 3.5 & +1 & 2 & 1 & -1 \\
\hline 7 & 3.5 & 5.5 & +2 & 2 & 3 & +1 \\
\hline 8 & 3 & 4 & +1 & 2 & 2.5 & +.5 \\
\hline 9 & 4.5 & 5 & +.5 & 2.5 & 2 & -.5 \\
\hline 10 & 5.5 & 6 & +.5 & 1 & 0 & -1 \\
\hline 11 & 2.5 & 3.5 & +1 & 4.5 & 4 & -.5 \\
\hline 12 & 3.5 & 2.5 & -1 & 1 & .5 & -.5 \\
\hline 13 & 6 & 4.5 & -1.5 & & & \\
\hline 14 & 4 & 4.5 & +.5 & & & \\
\hline 15 & 3.5 & 7 & +3.5 & & & \\
\hline
\end{tabular}


Table 4. Mean and standard deviation for pre-test and post-test of experimental group and controlled group in School A.

\begin{tabular}{ccccc}
\hline \multirow{2}{*}{ Group } & \multicolumn{2}{c}{ Pre-Test } & \multicolumn{2}{c}{ Post-Test } \\
\cline { 2 - 5 } & Mean & S.D. & Mean & S.D. \\
\hline Experimental & 3.8 & 1.3 & 4.9 & 1.6 \\
Controlled & 2.5 & 1.6 & 2.5 & 1.9 \\
\hline
\end{tabular}

Table 5. Paired-sample T-tests of the differences between the mean score for pre-test and post-test of experimental groups and controlled group in School A and School B.

\begin{tabular}{|c|c|c|c|c|c|c|c|c|c|}
\hline \multirow{2}{*}{\multicolumn{2}{|c|}{ Schools }} & \multirow[t]{2}{*}{$\begin{array}{c}\text { Mean } \\
\text { Diff }\end{array}$} & \multirow[t]{2}{*}{$\begin{array}{c}\text { Std. } \\
\text { Deviation }\end{array}$} & \multirow{2}{*}{$\begin{array}{l}\text { Std. } \\
\text { Error } \\
\text { Mean }\end{array}$} & \multicolumn{2}{|c|}{$\begin{array}{l}\text { 95\% Confidence } \\
\text { Interval of the } \\
\text { Difference }\end{array}$} & \multirow[t]{2}{*}{$\mathrm{t}$} & \multirow[t]{2}{*}{$\mathrm{df}$} & \multirow[t]{2}{*}{$\begin{array}{c}\text { Sig. } \\
\text { (2-tailed) }\end{array}$} \\
\hline & & & & & Lower & Upper & & & \\
\hline \multirow{2}{*}{$\begin{array}{l}\text { Experimental } \\
\text { group }\end{array}$} & School A & 1.067 & 1.321 & .341 & .335 & 1.798 & 3.127 & 14 & $.007^{\star}$ \\
\hline & School B & 1.000 & .756 & .195 & .581 & 1.419 & 5.123 & 14 & $.000^{*}$ \\
\hline $\begin{array}{l}\text { Controlled } \\
\text { group }\end{array}$ & School A & .000 & .707 & .204 & -.449 & .449 & .000 & 11 & 1.000 \\
\hline
\end{tabular}

\subsection{Participants Responses towards the Use of PaW-Modo}

PaW-Burger and PaW-Oreo were carried out during the intervention. During the course of the research, all participants of the experimental groups from both schools had undergone a questionnaire comprises 6 questions with 4 closed-ended questions and 2 open-ended questions, which aims to find out how the respondents feel about each activity. Table 6 and Table 7 are the respondents' response towards the use of PaW-Burger activities and PaW-Oreo activities in School A and School B.

Based on the result in Table 6 and Table 7, it was found that $80 \%$ of the respondents from both schools reacted positively towards the intervention of using $\mathrm{PaW}$-Modo in learning paragraph writing. The findings indicated that 13 (86.7\%) respondents from School A had exhibited interest towards PaW-Burger and PaW-Oreo, whereas none of the respondents (0\%) from School B showed disinterested towards PaW-Burger and PaW-Oreo. This positive attitude revealed that $\mathrm{PaW}$-Modo has the potential to be chosen for a paragraph writing lesson. Noviana, Rufinus, \& Bunau (2015) claimed that pupils may find a good reason to write when ICT is being used in teaching and learning writing. The customised teaching and learning materials in PaW-Burger and PaW-Oreo incorporated with the use of Edmodo further provide the pupils with variety of interesting writing topics so that the writing lessons appear to be more interesting.

$\mathrm{PaW}$-Modo is also portrayed as an interesting virtual classroom that motivates the learners to learn paragraph writing. The findings pointed out that $13(86.7 \%)$ respondents from School A wish to have writing activities again using PaW-Burger and PaW-Oreo activities. For School B, all the respondents (100\%) 
wish to have writing activities again using PaW-Burger and 14 (93.3\%) respondents wish to have writing activities again using PaW-Oreo. This finding is line with the study of Kreutz \& Rhodin (2016) who also discovered that the use of ICT could lead to positive motivational outcomes as ICT promotes interaction between learners, learners with teacher and learner with learning material through making comments, virtual group discussion and sharing their answers on the Edmodo group.

Moreover, the integration of ICT encourages learners to develop independent work habits and build both their skills and confidence in writing as the results of the questionnaires showed most of the respondents from both schools thought that they could write better using PaW-Modo and PaW-Oreo. Only 2 (13.3\%) respondents from School A and 1 (6.7\%) respondents from School B thought that they could not write better using PaW-Burger. Meanwhile, for PaW-Oreo activities, only 1 respondent from School A and 3 respondents from School B thought that they could not write better using PaW-Oreo.

Table 6. Respondents' response towards the use of PaW-Burger from School A and School B.

\begin{tabular}{ccccc}
\hline & \multicolumn{2}{c}{ School A } & \multicolumn{2}{c}{ School B } \\
\cline { 2 - 5 } & Yes & No & Yes & No \\
\hline $\begin{array}{c}\text { Are you interested in learning } \\
\text { paragraph writing using }\end{array}$ & 13 & 2 & 15 & 0 \\
PaW-Burger? & $(86.7 \%)$ & $(13.3 \%)$ & $(100 \%)$ & $(0 \%)$ \\
$\quad \begin{array}{c}\text { Do you wish to have writing } \\
\text { activities again using }\end{array}$ & 13 & 2 & 15 & 0 \\
$\quad$ PaW-Burger? & $(86.7 \%)$ & $(13.3 \%)$ & $(100 \%)$ & $(0 \%)$ \\
$\begin{array}{c}\text { Do you think you can write better using } \\
\text { PaW-Burger now? }\end{array}$ & 13 & 2 & 14 & 1 \\
$\quad \begin{array}{c}\text { Are you eager to read your friends' and } \\
\text { teachers' comments on your writing? }\end{array}$ & $(86.7 \%)$ & $(13.3 \%)$ & $(93.3 \%)$ & $(6.7 \%)$ \\
\hline
\end{tabular}

Table 7. Respondents' response towards the use of PaW-Oreo from School A and School B.

\begin{tabular}{ccccc}
\hline & \multicolumn{2}{c}{ School A } & \multicolumn{2}{c}{ School B } \\
\cline { 2 - 5 } & Yes & No & Yes & No \\
\hline $\begin{array}{c}\text { Are you interested in learning para- } \\
\text { graph writing using } \\
\text { PaW-Oreo? }\end{array}$ & 13 & 2 & 15 & 0 \\
$\begin{array}{c}\text { Do you wish to have writing activities } \\
\text { again using PaW-Oreo? }\end{array}$ & 13 & $(13.3 \%)$ & $(100 \%)$ & $(0 \%)$ \\
$\begin{array}{c}\text { Do you think you can write better using } \\
\text { PaW-Oreo now? }\end{array}$ & 14 & 2 & 14 & 1 \\
$\begin{array}{c}\text { Are you eager to read your } \\
\text { friends' and teachers' }\end{array}$ & $(96.7 \%)$ & $(13.3 \%)$ & $(93.3 \%)$ & $(6.7 \%)$ \\
comments on your writing? & $(86.7 \%)$ & $(6.7 \%)$ & $(73.3 \%)$ & $(26.7 \%)$ \\
\hline
\end{tabular}


Since peers' checking and teachers' grading were parts of the post-writing activities done during the intervention, the study also intended to find out how pupils perceived giving comments to and receiving feedbacks from others. For PaW-Burger activities, all the respondents from School A and 14 (93.3\%) respondents from School A were eager to read their friends' and teachers' comments on their writing. As for PaW-Oreo activities, 13 (86.7\%) respondents from School A and 14 (93.3\%) respondents from School B are interested to read their friends' and teachers' comments on their writing. As Yunus \& Salehi, 2012; Is'haq et al. (2018) pointed out in their study that social networking platforms could help pupils to improve writing skill through peers' feedback, thus, the respondents were followed up with open-ended questions "Do you learn from your friends' and your teachers' comments? What have you learnt?". The responses from the respondents implied that writing was seen as a collaborative task that promotes scaffolding and self-reflection through peer-editing. Most of the respondents claimed that they have learnt about writing with correct mechanism in terms of punctuations, capitalization and parts of speech. Quoted from some respondents:

Respondent 2: Yes, I have learnt my mistakes from their comments. For example, punctuation, capitalization, supporting detail.

Respondent 8: Yes, I have learnt to use punctuations correctly and how to write sentences.

Respondent 17: Yes, I learn my mistakes from their comments. I also learn to be careful in capitalization.

Besides that, another two open-ended questions were "What have you learnt through PaW-Burger?" and "What have you learnt through 'PaW-Oreo"'. The respondents were asked to list down two answers for both questions. The questions were intended to find out the how pupils perceive $\mathrm{PaW}$-Modo in helping them to write effectively in paragraph writing. It was found that the respondents were managed to learn the form of paragraph writing through PaW-Burger activities. Quoted some respondents:

Respondent 2: I learnt how to make sentences and write introduction of the paragraph.

Respondent 17: I have learnt topic sentence, details and concluding sentence.

They also agreed that they have learned and practised the way to write a complete paragraph through PaW-Oreo activities. Quoted some respondents:

Respondent 9: I have learnt how to write the conclusion and give reasons for my idea.

Respondent 21: I have learnt about how to use computer, how to write vocabulary that I don't know, how to pull words and write paragraph writing by using the format of O.RE.RE.RE.O.: I have learnt how to write conclusion and give reasons on my idea.

Respondent 27: I have learnt topic sentence, details and concluding sentence.

The responses indicated that using Edmodo as a teaching and learning virtual class to paragraph writing can be a promising and productive solution through 
the designation of PaW-Burger and PaW-Oreo activities.

\section{Conclusion and Implication}

Based on the findings done in two different schools, it was concluded that PaW-Modo is a useful strategy to assist the pupils in paragraph writing. The participants get to master the organisation in paragraph writing through the $\mathrm{PaW}$-Burger and PaW-Oreo activities. PaW-Modo activities have also proven that involvement among pupils via social learning platform like Edmodo will aid them in writing paragraph writing. Besides, the study also revealed the increasing engagement of pupils in designated activities and authentic networking built among pupils and teachers. In the future study, PaW-Modo could also possibly be adapted to other language skills that involve speaking, listening and reading skills. Replication and innovation on these Edmodo-based activities is also attainable for other languages too. This new way of paragraph writing learning acts as a platform to keep pupils active in writing and learning from comments with no time boundary. PaW-Modo breaks the barriers in the learning classroom and transforms it into positive learning environment. It creates a scaffolding learning environment among the pupils with higher writing skills and vocabulary and the passive pupils. These learners will be able to learn and get familiar with this way of learning in getting more knowledge and exposure in writing. It could enhance their interpersonal skills, thinking skills, independent learning skill and also increase their self-confidence in learning English writing when expressing opinions and ideas in pairs or in groups.

\section{Acknowledgements}

The researchers would like to thank the respondents and interviewees for providing rich and informative insights for the purpose of this study.

\section{Conflicts of Interest}

The authors declare no conflicts of interest regarding the publication of this paper.

\section{References}

Balasubramanian, K., Jaykumar, V., \& Fukey, L. N. (2014). A Study on Student Preference towards the Use of Edmodo as a Learning Platform to Create Responsible Learning Environment. Procedia-Social and Behavioral Sciences, 144, 416-422. https://doi.org/10.1016/j.sbspro.2014.07.311

Boholano, H. B. (2017). Smart Social Networking: 21st Century Teaching and Learning Skills. Research in Pedagogy, 7, 21-29. https://doi.org/10.17810/2015.45

Charoenwet, S., \& Christensen, A. (2016). The Effect of Edmodo Learning Network on students' Perception, Self-Regulated Learning Behaviors and Learning Performance. Proceedings of the 10th International Multi-Conference on Society, Cybernetics and Informatics, 297-300.

Damian, K., \& Yunus, M. M. (2016). The Effectiveness of Using Sentence Makers in Improving Writing Performance among Pupils in Lubok Antu Rural Schools. Interna- 
tional Conference on Education, 1, 469-475.

Ekici, D. I. (2017). The Use of Edmodo in Creating an Online Learning Community of Practice for Learning to Teach Science. Malaysia Online Journal of Educational Sciences, 5, 91-106.

Enriquez, M. A. (2014). Students' Perceptions on the Effectiveness of the Use of Edmodo as a Supplemtary Tool for Learning. The DLSU Research Congress, 1-6.

Fauzi, A. (2017). The Effect of Edmodo on Students' Writing Skill in Recount Text. International Journal of Pedagogy and Teacher Education, 1, 73-79. https://doi.org/10.20961/ijpte.v1i2.5038

Gagne, R. M., Briggs, L. J., \& Wagner, W. W. (1992). Principles of Instructional Design (5th ed.). Fort Worth: Harcourt Brace Jovanovich College Publishers.

Is'haq, N., Maryem, J., \& Iman, K. (2018). Promoting Students' Paragraph Writing Using Edmodo: An Action Research. Turkish Online Journal of Educational Technology, 17, 130-143.

Kreutz, J., \& Rhodin, N. (2016). The Influence of ICT on Learners' Motivation towards Learning English. Degree Project in English and Learning.

https://muep.mau.se/bitstream/handle/2043/20747/Degree\%20Project\%20Josefin\%20\& $\% 20$ Natalie.pdf? sequence $=2$

Lan, Y. F., Hung, C. L., \& Hsu, H. (2011). Effects of Guided Writing Strategies on Students' Writing Attitudes Based on Media Richness Theory. Turkish Online Journal of Educational Technology, 10, 148-164.

Noviana, O., Rufinus, A., \& Bunau, E. (2015). The Effective Use of Edmodo in Writing a Narrative Text in Senior High School. Ph.D Thesis, Pontianak: Tanjungpura University.

Purnawarman, P., Susilawati, S., \& Sundayana, W. (2015). The Use of Edmodo in Teaching Writing in a Blended Learning Setting. Indonesian Journal of Applied Linguistics, 5, 242-252. https://doi.org/10.17509/ijal.v5i2.1348

Qalaja, M. W. M. (2015). The Effectiveness of Using Edmodo on Developing Seventh Graders' Writing Skills and Their Attitude towards Writing in Gaza Governorate. http://library.iugaza.edu.ps/thesis/115053.pdf

Vanesa, D. L. (2013). The Improvement of Writing Based on a Genre Approach through the Use of an e-Learning Platform. Orizaba: Universidad Veracruzana. https://cdigital.uv.mx/bitstream/handle/123456789/35143/duranlaravanesa.pdf;jsession $\mathrm{id}=439 \mathrm{D} 932096 \mathrm{C} 6394873719 \mathrm{FF} 54 \mathrm{~B} 36 \mathrm{A26B}$ ? sequence $=2$

Yunus, M. M., \& Salehi, H. (2012). The Effectiveness of Facebook Groups on Teaching and Improving Writing: Students' Perceptions. International Journal of Education and Information Technologies, 1, 87-96.

Yunus, M. M., Nordin, N., Salehi, H., Choo, H. S., \& Embi, M. A. (2013a). Pros and Cons of Using ICT in Teaching ESL Reading and Writing. International Education Studies, 6, 119-130. https://doi.org/10.5539/ies.v6n7p119

Yunus, M. M., Nordin, N., Salehi, H., Embi, M. A., \& Salehi, Z. (2013b). The Use of Information and Communication Technology (ICT) in Teaching ESL Writing Skills. Canadian Center of Science and Education, 6, 1-8.

Zain, I. M. (2017). The Collaborative Instructional Design System (CIDS). Universal Journal of Educational Research, 5, 2259-2266. https://doi.org/10.13189/ujer.2017.051216

Zakaria, S. M., Yunus, M. M., Nazri, N. M., \& Shah, P. M. (2016). Students' Experience of Using Storybird in Writing ESL Narrative Text. Creative Education, 7, 2107-2120. https://doi.org/10.4236/ce.2016.715210 